Journal of Applied Pharmaceutical Science Vol. 5 (09), pp. 068-071, September, 2015

Available online at http://www.japsonline.com

DOI: $10.7324 /$ JAPS.2015.50913

ISSN 2231-3354 (cc) BY-NC-SA

\title{
Preliminary phytochemical screening, antihyperglycemic, analgesic and toxicity studies on methanolic extract of aerial parts of Corchorus olitorius L.
}

\author{
Sanjida Parvin ${ }^{1}$, Moytry Marzan ${ }^{1}$, Sanjana Rahman ${ }^{1}$, Anuj Kumer Das ${ }^{1}$, Sanjida Haque ${ }^{2}$, Mohammed Rahmatullah ${ }^{3 *}$ \\ ${ }^{1}$ Department of Biotechnology \& Genetic Engineering, University of Development Alternative, Dhanmondi, Dhaka-1209, Bangladesh. \\ ${ }^{2}$ Department of Pharmacy, Bangladesh University, Iqbal Road, Mohammadpur, Dhaka-1207, Bangladesh. \\ ${ }^{3}$ Department of Pharmacy, University of Development Alternative, Dhaka, Dhanmondi, Dhaka-1209, Bangladesh.
}

\section{ARTICLE INFO}

Article history:

Received on: 15/06/2015

Revised on: 10/07/2015

Accepted on: 30/07/2015

Available online: 27/09/2015

Key words:

Antihyperglycemic,

Corchorus olitorius,

analgesic, Tiliaceae

\begin{abstract}
Corchorus olitorius, also known as Nalta jute or Tossa jute is grown throughout Bangladesh for its fibre and because the aerial parts are edible. It was of interest to phytochemically screen and conduct antihyperglycemic, analgesic and toxicity studies of the aerial parts. Antihyperglycemic and analgesic activities, phytochemical screening and toxicity studies were done through standard methods. Administration of methanol extract of aerial parts (MECO) led to dose-dependent reductions in blood glucose levels in glucose-loaded mice. At doses of 50, 100,200 and $400 \mathrm{mg}$ per $\mathrm{kg}$, the extract reduced blood glucose levels by 18.6, 29.3, 32.9, and 50.7\%, respectively compared to control animals. By comparison, a standard antihyperglycemic drug, glibenclamide, when administered at a dose of $10 \mathrm{mg}$ per $\mathrm{kg}$, reduced blood glucose level by $48.9 \%$. In analgesic activity tests, MECO at doses of 50, 100, 200 and $400 \mathrm{mg}$ per kg reduced the number of writhings by 19.2, 42.3, 53.8, and $57.7 \%$, respectively. A standard analgesic drug, aspirin, reduced the number of writhings by 38.5 and $65.4 \%$, respectively, when administered at doses of 200 and $400 \mathrm{mg}$ per $\mathrm{kg}$. Phytochemical screening of MECO showed presence of alkaloids, flavonoids, saponins and tannins, which may be responsible for the observed effects.
\end{abstract}

\section{INTRODUCTION}

Corchorus olitorius L. (Tiliaceae), known in English as Nalta jute or Tossa jute, is widely cultivated in Bangladesh for its fibre and for its edible aerial parts. In Bangladesh the plant is known as 'mishti paat'. The plant is also considered to have ethnnomedicinal values. Cardenolide glycosides have been reported from seeds of the plant (Nakamura et al., 1998). Antiobesity effect of polyphenolic compounds from leaves of the plant has been reported in LDL receptor deficient mice (Wang et al., 2011). Anti-inflammatory effects of phenolic crude extracts from various parts of the plant have been demonstrated (Yan et al., 2013).

\footnotetext{
* Corresponding Author

Professor Dr. Mohammed Rahmatullah

Pro-Vice Chancellor and Dean, Faculty of Life Sciences, University of Development Alternative, House No. 78, Road No. 11A (new), Dhanmondi, Dhaka-1209. Bangladesh.Telephone: +88-01715032621, Fax: +88-02-815739. Email: rahmatm@uoda.edu.bd
}

Gastroprotective effects of leaf extract have been observed against ethanol-induced gastric mucosal hemorrhagic lesions in rats (Al Batran et al., 2013).

Diabetes and pain are endemic problems among the population of Bangladesh. Effective allopathic medicines are not available or affordable to the predominantly rural population. Towards finding alternate sources of easily available herbal medicines, we have been conducting extensive investigations of the medicinal plants of Bangladesh as to their antihyperglycemic and analgesic potential (Morshed et al., 2010; Rahmatullah et al., 2010; Ahmed et al., 2011; Shahreen et al., 2012; Haque et al., 2013; Rahmatullah et al., 2013a,b; Ghosh et al., 2014; Hossain et al., 2014; Jahan et al., 2014; Rahman et al., 2014; Tazin et al., 2014).

C. olitorius is one of the common plants of Bangladesh and widely cultivated. The objective of the present study was to evaluate the antihyperglycemic and analgesic potential of methanol extract of aerial parts of the plant along with preliminary phytochemical screening and toxicity studies on the extract. 


\section{MATERIALS AND METHODS}

\section{Plant material collection}

Aerial parts of $C$. olitorius were collected during September 2013 from Rayer Bazar in Dhaka, Bangladesh and taxonomically identified at the Bangladesh National Herbarium (Accession Number 38,715).

\section{Preparation of methanolic extract of aerial parts}

Aerial parts were cut into small pieces, air-dried in the shade, and $150 \mathrm{~g}$ of dried and powdered aerial parts were extracted with methanol (w:v ratio of 1:5, final weight of the extract $5.16 \mathrm{~g}$ ).

\section{Chemicals and Drugs}

Glibenclamide, aspirin, and glucose were obtained from Square Pharmaceuticals Ltd., Bangladesh. All other chemicals were of analytical grade.

\section{Animals}

Swiss albino mice, which weighed between $15-20 \mathrm{~g}$ were used in the present study. The animals were obtained from International Centre for Diarrhoeal Disease Research, Bangladesh (ICDDR,B). The animals were acclimatized for three days prior to actual experiments. The study was conducted following approval by the Institutional Animal Ethical Committee of University of Development Alternative, Dhaka, Bangladesh.

\section{Oral glucose tolerance tests for evaluation of antihyperglycemic activity}

Oral glucose tolerance tests (OGTT) were carried out as per the procedure previously described by Joy and Kuttan (1999) with minor modifications. Briefly, fasted mice were grouped into six groups of five mice each. The various groups received different treatments like Group 1 received vehicle (1\% Tween 80 in water, $10 \mathrm{ml} / \mathrm{kg}$ body weight) and served as control, Group 2 received standard drug (glibenclamide, $10 \mathrm{mg} / \mathrm{kg}$ body weight). Groups 3-6 received methanolic aerial part extract (MECO) at doses of 50, 100, 200 and $400 \mathrm{mg}$ per $\mathrm{kg}$ body weight. All substances were orally administered. Following a period of one hour, all mice were orally administered $2 \mathrm{~g}$ glucose $/ \mathrm{kg}$ of body weight. Blood samples were collected 120 minutes after the glucose administration through puncturing heart. Blood glucose levels were measured by glucose oxidase method (Venkatesh et al., 2004). The percent lowering of blood glucose levels were calculated according to the formula described below.

Percent lowering of blood glucose level $=\left(1-\mathrm{W}_{\mathrm{e}} / \mathrm{W}_{\mathrm{c}}\right) \mathrm{X} 100$, where $\mathrm{W}_{\mathrm{e}}$ and $\mathrm{W}_{\mathrm{c}}$ represents the blood glucose concentration in glibenclamide or MECO administered mice (Groups 2-6), and control mice (Group 1), respectively.

\section{Analgesic activity evaluation through abdominal writhing test}

Analgesic activity of MECO was examined as previously described (Shanmugasundaram and Venkataraman, 2005). Mice were divided into seven groups of five mice each. Group 1 served as control and was administered vehicle only. Groups 2 and 3 were orally administered the standard analgesic drug aspirin at doses of 200 and $400 \mathrm{mg}$ per $\mathrm{kg}$ body weight, respectively. Groups 4-7 were administered MECO at doses of 50, 100, 200 and $400 \mathrm{mg}$ per $\mathrm{kg}$ body weight, respectively.

Following a period of 60 minutes after oral administration of standard drug or MECO, all mice were intraperitoneally injected with $1 \%$ acetic acid at a dose of $10 \mathrm{ml}$ per $\mathrm{kg}$ body weight. A period of 5 minutes was given to each animal to ensure bioavailability and onset of chemically induced irritation of acetic acid (Akter et al., 2014), following which period, the number of abdominal constrictions (writhings) was counted for $10 \mathrm{~min}$. The percent inhibitions of abdominal constrictions were calculated according to the formula given below.

Percent inhibition $=\left(1-\mathrm{W}_{\mathrm{e}} / \mathrm{W}_{\mathrm{c}}\right) \times 100$

where $\mathrm{W}_{\mathrm{e}}$ and $\mathrm{W}_{\mathrm{c}}$ represents the number of writhings in aspirin or MECO administered mice (Groups 2-7), and control mice (Group $1)$, respectively.

\section{Acute toxicity test}

Acute toxicity test was conducted as previously described (Ganapaty et al., 2002). Mice were divided into nine groups, each group consisting of six animals. Group 1 was given $1 \%$ Tween 80 in normal saline ( $2 \mathrm{ml}$ per $\mathrm{kg}$ body weight). The other eight groups (Groups 2-9) were administered, respectively, 100, 200, 300, 600, 800, 1000, 2000 and $3000 \mathrm{mg}$ of MECO per $\mathrm{kg}$ body weight.

All animals were closely observed for the next 8 hours to notice any behavioral changes or mortality and were kept under close observation for the next two weeks.

\section{Statistical analysis}

Experimental values are expressed as mean \pm SEM. Independent Sample t-test was carried out for statistical comparison. Statistical significance was considered to be indicated by a p value $<0.05$ in all cases (Hossain et al., 2014).

\section{Preliminary phytochemical screening}

Preliminary phytochemical analysis of MECO for presence of saponins, tannins, alkaloids, and flavonoids were conducted as described before (Kumar et al., 2013).

\section{RESULTS AND DISCUSSION}

\section{Toxicity evaluation}

The crude extract (MECO) did not show any toxicity in mice even at the highest dose tested. There were no changes in behavioral pattern and mortality was not observed.

\section{Preliminary screening of phytochemicals}

Various tests conducted for presence of phytochemicals in MECO indicated the presence of alkaloids, flavonoids, saponins, and tannins. 


\section{Antihyperglycemic activity evaluation results}

In oral glucose tolerance tests, MECO when administered at doses of 50, 100, 200 and $400 \mathrm{mg}$ per kg body weight, dosedependently and significantly reduced the amount of blood glucose in experimental animals. At these four doses, MECO, respectively, decreased blood glucose levels by 18.6, 29.3, 32.9, and $50.7 \%$. A standard antihyperglycemic drug, glibenclamide when administered at a dose of $10 \mathrm{mg}$ per $\mathrm{kg}$ body weight, reduced blood glucose levels by $48.9 \%$. Thus MECO at the highest concentration tested showed better antihyperglycemic activity than glibenclamide. The results are shown in Table 1 and suggest that MECO can be used to lower blood glucose levels in hyperglycemic subjects.

Table 1: Effect of crude methanol extract of $C$. olitorius aerial parts (MECO) on blood glucose level in hyperglycemic mice following 120 minutes of glucose loading.

\begin{tabular}{lccc}
\hline Treatment & $\begin{array}{c}\text { Dose (mg/kg } \\
\text { body weight) }\end{array}$ & $\begin{array}{c}\text { Blood glucose } \\
\text { level (mmol/l) }\end{array}$ & $\begin{array}{c}\text { \% lowering of } \\
\text { blood glucose } \\
\text { level }\end{array}$ \\
\hline Control & $10 \mathrm{ml}$ & $5.60 \pm 0.27$ & - \\
Glibenclamide & $10 \mathrm{mg}$ & $2.86 \pm 0.26$ & $48.9^{*}$ \\
(MECO) & $50 \mathrm{mg}$ & $4.56 \pm 0.12$ & $18.6^{*}$ \\
(MECO) & $100 \mathrm{mg}$ & $3.96 \pm 0.33$ & $29.3^{*}$ \\
(MECO) & $200 \mathrm{mg}$ & $3.76 \pm 0.20$ & $32.9^{*}$ \\
(MECO) & $400 \mathrm{mg}$ & $2.76 \pm 0.28$ & $50.7^{*}$ \\
\hline
\end{tabular}

All administrations were made orally. Values represented as mean \pm SEM, $(\mathrm{n}=5) ;{ }^{*} P<0.05$; significant compared to hyperglycemic control animals.

The bioactive component(s) responsible for the antihyperglycemic activity or the mechanism through which MECO lowered blood glucose levels were not ascertained in this preliminary study and further work is being undertaken by us to determine them. However, the extract showed the presence of alkaloids, flavonoids, saponins and tannins. These groups of compounds have variously been reported by other authors to possess antihyperglycemic effects. For instance, the analgesic activity of Aconitum baikalnensis has been attributed to diterpene alkaloids (Nesterova et al., 2014).

Stem bark extract of Tamarindus indica reportedly demonstrated antihyperglycemic activity in alloxan diabetic rats. Phytochemical screening of the extract showed the presence of glycosides, saponins, flavonoids, cardiac glycosides, tannins, alkaloids and triterpenes (Yerima et al., 2014). The preliminary phytochemical analysis of an ethanolic extract of the whole plant of Tridax procumbens indicated the presence of alkaloids, tannins, flavonoids, saponins, and phenolic compounds. The ethanolic extract of the whole plant at 250 and $500 \mathrm{mg} / \mathrm{kg}$ demonstrated significant antidiabetic and antihyperlipidemic activities (Petchi et al., 2013).

\section{Analgesic activity evaluation results}

Dose-dependent and significant reductions in the number of abdominal constrictions induced by intraperitoneal administration of acetic acid were observed with MECO. At doses of 50,100, 200 and $400 \mathrm{mg}$ per $\mathrm{kg}$ body weight, MECO was observed to reduce the number of constrictions (writhings), respectively, by $19.2,42.3,53.8$, and $57.7 \%$. A standard analgesic drug, aspirin, when administered to experimental animals at doses of 200 and $400 \mathrm{mg}$ per $\mathrm{kg}$ body weight, reduced the number of constrictions by 38.5 and $65.4 \%$, respectively.

Thus, a dose of $100 \mathrm{mg} / \mathrm{kg}$ MECO showed better analgesic activity than that of $200 \mathrm{mg} / \mathrm{kg}$ aspirin. The results are shown in Table 2 and suggest that the extract possesses significant analgesic properties.

Table 2: Analgesic effect of crude methanol extract of $C$. olitorium aerial parts (MECO) in acetic acid-induced pain model mice.

\begin{tabular}{lccc}
\hline Treatment & $\begin{array}{c}\text { Dose (mg/kg } \\
\text { body weight) }\end{array}$ & $\begin{array}{c}\text { Mean number of } \\
\text { abdominal constrictions }\end{array}$ & $\begin{array}{c}\% \\
\text { inhibition }\end{array}$ \\
\hline Control & $10 \mathrm{ml}$ & $5.2 \pm 0.20$ & - \\
Aspirin & $200 \mathrm{mg}$ & $3.2 \pm 0.58$ & $38.5^{*}$ \\
Aspirin & $400 \mathrm{mg}$ & $1.8 \pm 0.58$ & $65.4^{*}$ \\
(MECO) & $50 \mathrm{mg}$ & $4.2 \pm 0.49$ & $19.2^{*}$ \\
(MECO) & $100 \mathrm{mg}$ & $3.0 \pm 0.55$ & $42.3^{*}$ \\
(MECO) & $200 \mathrm{mg}$ & $2.4 \pm 0.24$ & $53.8^{*}$ \\
(MECO) & $400 \mathrm{mg}$ & $2.2 \pm 0.37$ & $57.7^{*}$ \\
\hline All administrations (aspirin and extract) were made orally. Values represented \\
as mean \pm SEM, (n=5); $P<0.05 ;$ significant compared to control. \\
\multicolumn{4}{c}{ It is interesting to note that alkaloids, flavonoids, }
\end{tabular}
saponins and tannins (which are present in MECO) have also been implicated in showing analgesic effects. Pharmacognostic and phytochemical investigation of leaves of Malvastrum coromandelianum indicated presence of alkaloids, tannins and flavonoids along with analgesic and anti-inflammatory activities (Sanghai et al., 2013). Phytochemical analysis of the ethanolic extract of Sida cordifolia roots exhibiting analgesic activity indicated the presence of reducing sugar, alkaloids, steroids and saponins, which components were deemed responsible for the observed analgesic effects (Momin et al., 2014).

Aqueous extract of Vernonia condensata leaves has been reported to exhibit antinociceptive activity in writhing tests; the extract was found to contain alkaloids, flavonoids, and saponins (Risso et al., 2010). Thus these four groups of compounds, namely alkaloids, flavonoids, saponins and tannins can be responsible for the observed antihyperglycemic and analgesic effects of methanolic extract of aerial parts of $C$. olitorius. Since the plant is easily available, it opens up possibilities of obtaining new blood sugar lowering and pain alleviating drugs from the plant. The crude extract may itself serve the same purpose since it did not show any toxic effects.

\section{CONCLUSION}

The results suggest that methanolic extract of $C$. olitorius aerial parts can be used for lowering of blood glucose and for alleviating pain.

\section{ACKNOWLEDGEMENTS}

The authors thank Shahnaz Rahman and Erena Islam for their help in the experiments. The authors also declare that they have no conflicts of interest. 


\section{REFERENCES}

Ahmed F, Rahman S, Ahmed N, Hossain M, Biswas A, Sarkar S, Banna H, Khatun MA, Chowdhury MH, Rahmatullah M. Evaluation of Neolamarckia cadamba (Roxb.) Bosser leaf extract on glucose tolerance in glucose-induced hyhperglycemic mice. Afr J Trad Complement Altern Med, 2011; 8:79-81.

Akter M, Mitu IZ, Proma JJ, Rahman SM, Islam MR, Rahman $S$, Rahmatullah M. Antihyperglycemic and antinociceptive activity evaluation of methanolic extract of Trichosanthes anguina fruits in Swiss albino mice. Adv Nat Appl Sci, 2014; 8:70-74.

Al Batran R, Al-Bayaty F, Abdulla MA, Al-Obaidi MM, Hajrezaei M, Hassandarvish P, Fouad M, Golbabapour S, Talaee S. Gastroprotective effects of Corchorus olitorius leaf extract against ethanol -induced gastric mucosal hemorrhagic lesions in rats. J Gastroenterol Hepatol, 2013; 28:1321-1329.

Ganapaty S, Dash GK, Subburaju T, Suresh P. Diuretic, laxative and toxicity studies of Cocculus hirsutus aerial parts. Fitoterapia, 2002; 73:28-31.

Ghosh D, Mandal I, Rumi JF, Trisha UK, Jannat H, Ahmed M, Rahmatullah M. Effect of Allium sativum leaf extracts on glucose tolerance in glucose-induced htperglycemic mice. Adv Nat Appl Sci, 2014; 8:66-69.

Haque ME, Rahman S, Rahmatullah M, Jahan R. Evaluation of antihyperglycemic and antinociceptive activity of Xanthium indicum stem extract in Swiss albino mice. BMC Complement Alternat Med, 2013; 13:296-299.

Hossain AI, Faisal M, Rahman S, Jahan R, Rahmatullah M. A preliminary evaluation of antihyperglycemic and analgesic activity of Alternanthera sessilis aerial parts. BMC Complement Alternat Med, 2014; 14:169-173.

Jahan S, Rahmatullah M. Methanolic extract of aerial parts of Raphanus sativus var. hortensis shows antihyperglycemic and antinociceptive potential. World J Pharm Pharmaceut Sci, 2014; 3:193202.

Joy KL, Kuttan RJ. Anti-diabetic activity of Picrorrhiza kurroa extract. J Ethnopharmacol, 1999; 67:143-148.

Kumar C, Kumar R, Nehar S. Phytochemical properties, total antioxidant status of acetone and methanol extract of Terminalia arjuna Roxb. bark and its hypoglycemic effect on Type-II diabetic albino rats. J Pharmacogn Phytochem, 2013; 2:199-208.

Momin MA, Bellah SF, Rahman SM, Rahman AA, Murshid GM, Emran TB. Phytopharmacological evaluation of ethanol extract of Sida cordifolia L. roots. Asian Pac J Trop Biomed, 2014; 4:1824.

Morshed A, Hossain MH, Shakil S, Nahar K, Rahman S, Ferdausi D, Hossain T, Ahmad I, Chowdhury MH, Rahmatullah M. Evaluation of antinociceptive activity of two Bangladeshi medicinal plants, Kalanchoe pinnata (Lam.) Pers. and Lagerstroemia speciosa (L.) Pers. Adv Nat Appl Sci, 2010; 4:193-197.

Nakamura T, Goda Y, Sakai S, Kondo K, Akiyama H, Toyoda M. Cardenolide glycosides from seeds of Corchorus olitorius. Phytochemistry, 1998; 49:2097-2101.

Nesterova YV, Povet'yeva TN, Suslov NI, Zyuz'kov GN, Pushkarskii SV, Aksinenko SG, Schultz EE, Kravtsova SS, Krapivin AV. Analgesic activity of diterpene alkaloids from Aconitum baikalensis. Bull Exp Biol Med, 2014; 157:488-491.

Petchi RR, Parasuraman S, Vijaya C. Antidiabetic and antihyperlipidemic effects of an ethanolic extract of the whole plant of Tridax procumbens (Linn.) in streptozotocin-induced diabetic rats. J Basic Clin Pharm, 2013; 4:88-92.

Rahman S, Jahan R, Rahmatullah M. Effect of paddy husk extracts on glucose tolerance in glucose-induced hyperglycemic mice. World J Pharm Pharmaceut Sci, 2014; 3:111-120.
Rahmatullah M, Sultan S, Toma TT, Lucky SS, Chowdhury MH, Haque WM, Annay MEA, Jahan R. Effect of Cuscuta reflexa stem and Calotropis procera leaf extracts on glucose tolerance in glucoseinduced hyperglycemic rats and mice. Afr J Trad Complement Altern Med, 2010; 7:109-112.

Rahmatullah M, Hosain M, Rahman S, Rahman S, Akter M, Rahman F, Rehana F, Munmun M, Kalpana MA. Antihyperglycaemic and antinociceptive activity evaluation of methanolic extract of whole plant of Amaranthus tricolour L. (Amaranthaceae). Afr J Trad Complement Altern Med, 2013a; 10:408-411.

Rahmatullah M, Hossain M, Mahmud A, Sultana N, Rahman SM, Islam MR, Khatoon MS, Jahan S, Islam F. Antihyperglycemic and antinociceptive activity evaluation of 'khoyer' prepared from boiling the wood of Acacia catechu in water. Afr J Trad Complement Altern Med, 2013b; 10:1-5.

Risso WE, Scarminio IS, Moreira EG. Antinociceptive and acute toxicity evaluation of Vernonia condensata Baker leaves extracted with different solvents and their mixtures. Indian J Exp Biol, 2010; 48:811-816.

Sanghai DB, Kumar SV, Srinivasan KK, Aswatharam HN, Shreedhara CS. Pharmacognostic and phytochemical investigation of the leaves of Malvastrum coromandelianum (L.) Garcke. Anc Sci Life, 2013; 33:39-44.

Shahreen S, Banik J, Hafiz A, Rahman S, Zaman AT, Shoyeb MA, Chowdhury MH, Rahmatullah M. Antihyperglycemic activities of leaves of three edible fruit plants (Averrhoa carambola, Ficus hispida and Syzygium samarangense) of Bangladesh. Afr J Trad Complement Altern Med, 2012; 9:287-291.

Shanmugasundaram P, Venkataraman S. Anti-nociceptive activity of Hygrophilous auriculata (Schum) Heine. Afr J Tradit Complement Altern Med, 2005; 2:62-69.

Tazin TQ, Rumi JF, Rahman S, Al-Nahain A, Jahan R, Rahmatullah M. Oral glucose tolerance and antinociceptive activity evaluation of methanolic extract of Vigna unguiculata ssp. unguiculata beans. World J Pharm Pharmaceut Sci, 2014; 3:28-37.

Venkatesh S, Reddy GD, Reddy YSR, Sathyavathy D, Reddy B. Effect of Helicteres isora root extracts on glucose tolerance in glucoseinduced hyperglycemic rats. Fitoterapia, 2004; 75:364-367.

Wang L, Yamasaki M, Katsube T, Sun X, Yamasaki Y, Shiwaku K. Antiobesity effect of polyphenolic compounds from molokheiya (Corchorus olitorius L.) leaves in LDL receptor-deficient mice. Eur J Nutr, 2011; 50:127-133.

Yan YY, Wang YW, Chen SL, Zhuang SR, Wang CK. Antiinflammatory effects of phenolic crude extracts from five fractions of Corchorus Olitorius L. Food Chem, 2013; 138:1008-1014.

Yerima M, Anuka JA, Salawu OA, Abdu-Aguye I. Antihyperglycaemic activity of the stem-bark extract of Tamarindus indica L. on experimentally induced hyperglycaemic and normoglycaemic Wistar rats. Pak J Biol Sci, 2014; 17:414-418.

\section{How to cite this article:}

Sanjida Parvin, Moytry Marzan, Sanjana Rahman, Anuj Kumer Das, Sanjida Haque, Mohammed Rahmatullah. Preliminary phytochemical screening, antihyperglycemic, analgesic and toxicity studies on methanolic extract of aerial parts of Corchorus olitorius L. J App Pharm Sci, 2015; 5 (09): 068-071. 